\title{
PENGATURAN KANAL FREKUENSI RADIO BAGI MEDIA TELEVISI DALAM PERSPEKTIF UNDANG-UNDANG NOMOR 32 TAHUN 2002, TENTANG PENYIARAN DAN UNDANG-UNDANG NOMOR 5 TAHUN 1999 TENTANG LARANGAN PRAKTEK MONOPOLI DAN PERSAINGAN USAHA TIDAK SEHAT ${ }^{1}$
}

\author{
Rahmadan Hasbiansyah
}

\section{Abstrak}

The canal of broadcasting frequency is a scarce natural resource that has been public interests for specific broadcasting and communication needs. It strategic's function needs regulation to awarding wealhtness through Indonesian people. On the author's thought the existing regulation is deemed had not given just for wider interests party. The continuing facts is shown domination toward broadcasting frequency control through 10 of 14 of frequency canals by private television stations. The author here elaborates how the canal of broadcasting frequency ought to govern to preserve just in pratice and in the right way to ensure people prosperity.

Kata kunci: hukum persaingan usaha, monopoli, kanal frekuensi, radio

\section{Pendahuluan}

\section{A. Latar Belakang}

Semarak industri pertelevisian Indonesia saat ini memasuki era baru semenjak disahkannya Undang-Undang Nomor 32 Tahun 2002 Tentang Penyiaran (UU No.32/2002), pasalnya undang-undang ini telah mengganti keberadaan Undang-Undang Nomor 24 Tahun 1997 Tentang Penyiaran yang dianggap kurang sesuai lagi dengan perkembangan waktu. $^{2}$ Salah satu hal yang disesuaikan dengan Tahun 2007.

${ }^{1}$ Tulisan ini sudah diajukan untuk mengikuti seleksi Mahasiswa Berprestasi FHUI

${ }^{2}$ UU Penyiaran No. 24/1997 yang dinilai banyak kalangan -terutama pengamat dan praktisi penyiaran-sebagai "tidak demokratis". Disamping munculnya banyak cek kosong yang mengharuskan UU yang terdiri dari $12 \mathrm{Bab}$ dan 78 pasal tersebut mendelegasikan 26 pasal dilengkapi PP, sembilan masalah diatur dalam Keppres dan lima masalah mesti diatur oleh 
perkembangan waktu saat ini dalam UU No.32/2002, adalah mengenai desentralisasi $i^{3}$ penyiaran, ${ }^{4}$ pengaturan hal ini sejalan dengan semangat otonomi daerah yang ditegaskan dalam pasal 22, Undang-Undang Nomor 32 Tahun 2004 Tentang Pemerintahan Daerah (UU No.32/2004).

Dalam mewujudkan desentralisasi penyiaran ${ }^{5}$ itu, peran media khususnya media televisi tentunya sangat dibutuhkan. Peran televisi bagi perwujudan desentralisasi penyiaran ini tentunya dilakukan dengan menyuguhkan siaran-siaran lokal yang berpijak pada prinsip diversity of content dan diversity of omership. ${ }^{6}$

Keputusan Menteri Penerangan. Akibatnya, intervensi penguasa atas masalah penyiaran dalam UU No. 24 memang sangat menonjol. "Menunggu RUU Penyiaran Paling Demokratis". $<w w w . i m i p c . o r . i d / i n d /$ publication/ar_newsletter/1jan-mar2001/index>. diakses pada 13 April 2007.

3 Desentralisasi adalah penyerahan wewenang pemerintahan oleh Pemerintah kepada daerah otonom untuk mengatur dan mengurus urusan pemerintahan dalam sistem Negara Kesatuan Republik Indonesia. Indonesia, Undang-undang Tentang Pemerintahan Daerah, UU No.32 Tahun 2004. LN No. 125 Tahun 2004, TLN No.4437. Pasal 1 angka 7.

${ }^{4}$ Dalam UU No. 32/2002, tidak dijelaskan secara eksplisit perihal desentralisasi penyiaran tersebut. namun secara implisit hal tersebut menjadi salah satu pertimbangan mengapa undang-undang terkait disusun. Hal ini tercermin dari rumusan pada huruf $\mathrm{c}$ bagian pertimbangan undang-undang itu, yang pada intinya menyebutkan bahwa penyiaran nasional diselenggarakan untuk menjaga integrasi nasional. kemajemukan bangsa, dan untuk menjami terlaksananya otonomi daerah.

5 Desentralisasi penyiaran akan dapat meningkatkan partisipasi publik daerah. Dalam hal ini partisipasi publik itu direalisasikan pada berbagai bidang. Sebagai contoh dalam bidang pendidikan, dengan desentralisasi penyiaran maka transfer ilmu pengetahuan akan lebih efektif, karena tayangan yang disajikan setiap televisi lokal akan berorientasi dengan kondisi masyarakat di daerah sekitar, sebagai contoh acara televisi lokal yang membawakan siaran pertanian seperti budidaya lele dumbo atau teknik biogenetika pembibitan unggulan ternyata memberi manfaat besar bagi para petani yang ada di daerah-daerah. Dengan acaraacara itu maka tentunya industri lele dumbo dan/atau biogenetika tersebut akan dapat lebih berkembang. pasalnya pengetahuan petani akan industri itu juga sudah meningkat karenanya. Kemudian pada akhirnya, hal ini juga akan meningkatkan daya saing Indonesia pada industri itu di tingkat Internasional. Dengan ini maka jelas bahwa desentralisasi penyiaran dapat meningkatkan daya saing bangsa. Sumber acara lele dumbo dan biogenetika penulis dapat dari: "Semarak Televisi Lokal", http://agustianwar.multiply.com/tag/publik>, diakses pada 13 April 2007. April 2007.

6. "PP Penyiaran dan Demokratisasi". <www.pikiran-rakyat.com>. diakses pada 13 
Berbicara mengenai siaran televisi, maka patut juga dibicarakan mengenai kanal frekuensi radio $^{7}$, pasalnya melalui kanal inilah kegiatan penyiaran media televisi dilakukan. Saat ini kanal frekuensi radio yang didedikasikan untuk siaran televisi berjumlah maksimum hanya 14 kanal untuk setiap daerah. Dari 14 kanal tersebut. II diantaranya telah dipergunakan oleh RCTI, TPI, Indosiar, ANTEVE. Global TV, Metro TV, SCTV, Lativi, TV 7, Trans TV, dan TVRI. Sisa 3 kanal yang tersedia dicadangkan 1 kanal untuk kepentingan pertahanan dan keamanan dan 1 kanal untuk percobaan siaran digital. Dalam hal ini praktis kanal yang tersisa untuk televisi lokal disetiap daerah hanya 1 (satu) kanal. ${ }^{8}$ Kondisi ini selain dapat mengahambat masyarakat dapat berpartisipasi melalui kegiatan penyiaran", juga dapat berdampak pada persaingan di antara stasiun-staisun televisi yang menggunakan kanal-kanal itu. ${ }^{10}$

Berkaitan dengan kondisi di atas, penulis hendak mengetahui secara mendalam mengenai, bagaimanakah pengaturan kanal frekuensi radio yang sejalan dengan dengan UU No.32/2002 dan UndangUndang No.5 Tahun 1999 Tentang Larangan Praktek Monopoli dan Persaingan Usaha Tidak Sehat (UU No.5/1999), serta apakah pengaturan kanal frekuensi radio saat ini telah sejalan dengan kedua undang-undang tersebut di atas. Sehubungan dengan hal tersebut, maka penulis membuat karya tulis dengan judul sebagaimana dituliskan pada bagian cover tulisan ini.

\section{B. Pokok Permasalahan}

Berdasarkan uraian pada bagian latar belakang permasalahan yang telah penulis uraikan sebelumnya, maka ditemukan beberapa permasalahan yang akan lebih lanjut penulis ulas pada bab-bab

Kanal trekuensi radio merupakan bagian kecil dari spektrum frekuensi radio. Dalam UU No. $32 / 2002$ disebutkan bahwa spektrum frekuensi radio itu adalah ranah publik yang terbatas. Keterbatasan itu tentunya juga menjadikan kanai frekuensi radio meniadi terbatas. (Edisi VII): 10.

"Elpi Nazmuzzaman. "Persaingan TV Swasta: Nasional atau Lokal?". Kompetisi $32 / 2002$

\footnotetext{
"Partisipasi masyarakat merupakan salah satu hal yang diamanati dalam ItU No.
} 
berikutnya karya tulis ini. Adapun permasalahan-permasalahan tersebut antara lain:

1. bagaimanakah pengaturan kanal frekuensi radio yang sejalan dengan dengan UU No.32/2002 dan UU No.5/1999?

2. apakah pengaturan kanal frekuensi radio saat ini telah sejalan dengan kedua undang-undang tersebut di atas?

\section{Metode Penulisan}

Dalam menyusun penulisan ini, penulis melakukan kajian melalui:

1. Studi kepustakaan yaitu memperoleh data dari bahan kepustakaan yang berupa data sekunder". Data sekunder yang digunakan dalam penulisan ini bersumber dari:

a. bahan hukum primer yaitu bahan yang mempunyai kekuatan hukum mengikat dan berkaitan dengan masalah yang dibahas, seperti UU No.32/2002, UU No.32/2004, Peraturan Pemerintah Nomor 50 Tahun 2005 Tentang Penyelenggaraan Penyiaran (PP No.50/2005), Keputusan Menteri Perhubungan Nomor: KM.76 Tahun 2003 Tentang Rencana Induk (Master Plan) Frekuensi Radio Penyelenggaraan Telekomunikasi Khusus Untuk Keperluan Televisi Siaran Analog Pada Pita Ultra High Frequency (UHF) (KEPMENHUB No.KM.76/2003) dan UU No.5/1999.

b. bahan hukum sekunder yaitu bahan yang menjelaskan bahan hukum primer, seperti buku, diktat, berbagai artikel dari majalah. internet, dan lain-lain

c. bahan hukum tertier yaitu bahan yang memberikan penjelasan terhadap bahan hukum primer dan bahan hukum sekunder, seperti Kamus Bahasa Indonesia, Kamus Hukum dan Ensiklopedia.

2. Studi Lapangan yaitu memperoleh data dari lapangan berupa wawancara, dengan narasumber yang langsung berhubungan ataupun mengetahui mengenai tema penulisan.

Ditinjau dari sifatnya, tipologi penelitian dalam penulisan ini adalah penelitian deskriftif analitis, karena penulisan ini bertujuan

"Socrjono Soekanto dan Sri Mamudji, "Penelitian Hukum Normatif". cet. 1.. (Jakarta: Rajawali Pers. 1985), hal .14. 
untuk menjelaskan secara mendalam hal mengenai pengaturan kanal frekuensi radio yang sesuai UU No.32/2002 dan UU No.5/1999, kemudian juga untuk menjelaskan apakah aturan mengenai kanal frekuensi radio itu telah sesuai dengan kedua instrumen undangundang tersebut.

II. Tinjauan Umum Ketentuan yang Berkaitan dengan Pengaturan Kanal Frekuensi Pada UU No. 32/2002, dan UU No.5/1999

\section{A. Tinjauan atas UU No.32/2002}

\section{Asas, Tujuan, Fungsi dan Arah Hukum Penyiaran}

Penyiaran diselenggarakan berdasarkan Pancasila dan Undang-Undang Dasar Negara Republik Indonesia Tahun 1945 dengan asas manfaat, adil dan merata, kepastian hukum. keamanan, keberagaman, kemitraan, etika, kemandirian. kebebasan, dan tanggung jawab. ${ }^{12}$

Dimana asas tersebut di atas, merupakan suatu landas pikir bagi pencapaian tujuan penyelenggaraan penyiaran itu sendiri. yaitu untuk memperkukuh integrasi nasional, terbinanya watak dan jati diri bangsa yang beriman dan bertakwa, mencerdaskan kehidupan bangsa, memajukan kesejahteraan umum, dalam rangka membangun masyarakat yang mandiri, demokratis, adil dan sejahtera, serta menumbuhkan industri penyiaran Indonesia. ${ }^{13}$

Fungsi Penyiaran sebagai alat komunikasi massa digunakan untuk sarana informasi, pendidikan, hiburan yang sehat, kontrol dan perekat sosial. Dalam menjalankan fungsi tersebut, penyiaran juga mempunyai fungsi ekonomi dan kebudayaan. ${ }^{14}$

Arah penyelenggaraan penyiaran terkait dapat dicapai dengan menjunjung tinggi pelaksanaan Pancasila dan UndangUndang Dasar Negara Republik Indonesia Tahun 1945; menjaga dan meningkatkan moralitas dan nilai-nilai agama serta jati diri bangsa; meningkatkan kualitas sumber daya manusia; menjaga dan mempererat persatuan dan kesatuan bangsa: meningkatkan

\footnotetext{
${ }^{12}$ Indonesia (A). Undang-undang Tentang Penyiaran, Op. Cit.. Pasal 2.

${ }^{13}$ Ibid. Pasal 3.

${ }^{14}$ Ibid., Pasal 4.
} 
kesadaran ketaatan hukum dan disiplin nasional; menyalurkan pendapat umum serta mendorong peran aktif masyarakat dalam pembangunan nasional dan daerah serta melestarikan lingkungan hidup; mencegah monopoli kepemilikan dan mendukung persaingan yang sehat- di bidang penyiaran; mendorong peningkatan kemampuan perekonomian rakyat, mewujudkan pemerataan, dan memperkuat daya saing bangsa dalam era globalisasi; memberikan informasi yang benar, seimbang, dan bertanggung jawab; memajukan kebudayaan nasional. ${ }^{15}$

\section{Penyelenggaraan Penyiaran di Indonesia dan Jaminan Negara dalam Kegiatan Penyiaran}

Penyelenggaraan penyiaran didasarkan pada jaminan dari negara pada kegiatan penyiaran itu sendiri, yaitu untuk menyelenggarakan penyiaran bagi sebesar-besarnya kemakmuran masyarakat. ${ }^{16}$ Untuk mewujudkan hal ini, maka publik harus memiliki akses yang memadai untuk dapat terlibat, memanfaatkan, mendapatkan perlindungan, serta mendapatkan keuntungan dari kegiatan penyiaran. Cara-cara untuk mewujudkan jaminan tersebut yang kemudian disebut dengan prinsip keterbukaan akses partisipasi, perlindungan dan kontrol publik. Guna mencapai keberhasilan dari prinsip ini, maka juga dibutuhkan prinsip lain, yang secara melekat (embedded) menyokongnya, yakni prinsip diversity of ownership (keberagaman kepemilikan) dan diversity of content (keberagaman isi) dari lembaga penyiaran. Dengan kedua prinsip diversity ini diharapkan, negara dapat melakukan penjaminan terhadap publik melalui penciptaan iklim kompetitif antar lembaga penyiaran agar bersaing secara sehat dalam menyediakan pelayanan informasi yang terbaik kepada publik. Penjelasan prinsip-prinsip tersebut di atas adalah sebagai berikut:

a. Prinsip keterbukaan akses, partisipasi, perlindungan dan kontrol publik

Prinsip ini membuka peluang akses bagi setiap warga negara untuk menggunakan dan mengembangkan penyelenggaraan penyiaran nasional. Ini berarti prinsip ini memberi hak, kewajiban

Is Ibid. Pasal 5.

${ }^{16}$ Ibid., Pasal 6. 
dan tanggungjawab serta partisipasi masyarakat untuk mengembangkan penyiaran, seperti mengembangkan pribadi dan lingkungan sosialnya, mencari, memperoleh, memiliki dan menyimpan, mengolah dan menyampaikan informasi di lembaga penyiaran serta mengembangkan kegiatan literasi dan/atau pemantauan untuk mengawasi dan melindungi publik dari isi siaran yang merugikan mereka..

\section{b. Prinsip Diversity of ownership (keberagaman kepemilikan)}

Gelombang radio merupakan sumber daya alam yang terbatas (dalam ketakterbatasan inovasi teknologi) dan bagian dari ranah publik, yang penggunaannya ditujukan untuk sebesar-besarnya kemakmuran rakyat, utamanya berupa kebebasan untuk berkomunikasi dan memperoleh informasi. Prinsip diversity of ownership ditujukan agar tidak terjadi konsentrasi kepemilikan modal (capital) dalam lembaga penyiaran, serta saat bersamaan diarahkan untuk mendorong adanya pelibatan modal dari masyarakat luas di Indonesia. Oleh karena itu prinsip diversity of ownership menjadi prinsip dasar yang harus dipegang teguh untuk menciptakan sistem persaingan yang sehat, mencegah terjadinya monopoli dan oligopoli, serta memiliki manfaat ekonomi bagi masyarakat luas.

\section{c. Prinsip Diversity of content (keberagaman isi)}

Prinsip ini masih terkait erat dengan prinsip diversity of ownership. Salah satu esensi dari demokrasi adalah adanya jaminan kebebasan bagi munculnya berbagai ragam opini. Melalui prinsip diversity of content berarti menjamin keberagaman isi siaran, yang selaras dengan semangat dan eksistensi kultur bangsa Indonesia yang heterogen dan pluralis. Artinya, berbagai kelompok budaya, etnik, agama, ras dan golongan mempunyai posisi dan peluang yang sama dalam penyiaran. ${ }^{17}$

17 "Ketentuan UU No. 32 tahun 2002 tentang Penyiaran terkait Haluan Dasar. Karakteristih Penyiaran. dan Prinsip Dasar Penyiaran di Indonesia”. <www.kpi.go id>. diakses pada 07 September 2006. 


\section{B. Tinjauan atas UU No.5/1999}

\section{Asas dan Tujuan Hukum Persaingan Usaha}

Berbicara mengenai asas hukum, berarti berbicara mengenai pikiran dasar atau hal yang melatar belakangi suatu pembentukan dari suatu peraturan perundang-undangan ${ }^{18}$. Dalam kaitannya dengan persaingan usaha, dapat diketahui bahwa latar belakang diaturnya permasalahan ini adalah sebagaimana ditegaskan pada pasal 2 Undang-Undang No. 5 Tahun 1999, yang berbunyi: "pelaku usaha di Indonesia dalam menjalankan kegiatan usahanya berasaskan demokrasi ekonomi dengan memperhatikan keseimbangan antara kepentingan pelaku usaha dan kepentingan umum".

Demokrasi ekonomi dapat diartikan sebagai gagasan atau pandangan hidup yang mengutamakan persamaan hak dan kewajiban. ${ }^{19}$ Dari pengertian tersebut, terlihat bahwa pada demokrasi ekonomi, terdapat suatu semangat kebersamaan yang jika diimplementasikan dalam dunia persaingan usaha, maka penerapan ide tersebut diwujudkan dengan memberikan kesempatan yang sama bagi setiap individu dalam suatu masyarakat pada negara terkait, untuk berusaha dengan adil, sehingga akan terwujud suatu sistem pasar terbuka (Open Market), yaitu suatu sistem pasar di mana para pelaku usaha akan bebas memasuki pasar tanpa adanya suatu rintangan yang sengaja dibuat (artificial barrier), baik oleh pemerintah maupun oleh pelaku usaha tertentu, untuk menghambat atau menghalangi pelaku usaha lain untuk masuk ke dalam pasar terkait. ${ }^{20}$

Tujuan Hukum Persaingan Usaha secara tersirat terdapat pada bagian konsiderans dan secara tegas tercantum di dalam pasal 3 Undang-Undang Persaingan Usaha. Tiga tujuan umum Hukum Persaingan Usaha yang dapat ditarik dari konsiderans

18 Sudikno Mertokusumo. "Mengenal Hukum: Suatu Pengantar", Cetakan ke-4. (Yogyakarta: Liberty. 1995), hal. 34.

1.9 Jham Gunawan dan M. Martinus Sahrani, "Kamus Hukum", (Jakarta: Restu Agung, 2002), hal. 77

${ }^{20}$ Asril Sitompul. "Praktek Monopoli dan Persaingan Usaha Tidak Sehat: Tinjauan Terhadap Undang-undang Nomor 5 Tahun 1999", cet.1, 9, (Bandung: Citra Aditya Bakti. 1999), hal. 13. 
Undang-Undang Persaingan Usaha itu adalah: Pertama, bahwa Undang-Undang Persaingan Usaha dirancang untuk mengarahkan pembangunan ekonomi kepada terwujudnya kesejahteraan rakyat berdasarkan Pancasila dan Undang-Undang Dasar 1945. Kedua, Undang-Undang Persaingan Usaha disusun untuk mewujudkan demokrasi ekonomi ekonomi yang menghendaki adanya kesempatan yang sama bagi setiap warga negara yang ikut serta dalam proses produksi dan pemasaran barang dan atau jasa dalam iklim usaha yang sehat dan kondusif bagi pertumbuhan ekonomi dan bekerjanya mekanisme ekonomi pasar secara wajar. Ketiga, secara tersirat juga dinyatakan bahwa Undang-Undang Persaingan Usaha dimaksudkan untuk mencegah pemusatan ekonomi pada pelaku usaha tertentu. ${ }^{21}$

Kemudian, secara tegas tujuan Hukum Persaingan Usaha terdapat pada pasal 3 UU Anti Monopoli, yaitu:

1. menjaga kepentingan umum dan meningkatkan efisiensi ekonomi nasional sebagai salah satu upaya untuk meningkatkan kesejahteraan rakyat;

2. mewujudkan iklim usaha yang kondusif melalui pengaturan persaingan usaha yang sehat sehingga menjamin adanya kepastian kesempatan berusaha yang sama bagi pelaku usaha besar, pelaku usaha menengah, dan pelaku usaha kecil;

3. mencegah praktek monopoli dan atau persaingan usaha tidak sehat yang ditimbulkan oleh pelaku usaha;

4. terciptanya efektivitas dan efisiensi dalam kegiatan usaha. ${ }^{22}$

Tujuan-tujuan yang hendak dicapai sebagaimana dirinci dalam Pasal 3 tersebut akan menghadirkan persaingan usaha yang sehat yang akan memaksimalkan kesejahteraan konsumen. Secara ekonomi terdapat dua cara yang dapat ditempuh untuk mewujudkan hal tersebut, yaitu:

1. allocative efficiency (yaitu membuat barang atau jasa yang dikehendaki oleh masyarakat, yang ditunjukkan oleh kemauan konsumen untuk membayarnya);

${ }^{2 t}$ Arie Siswanto, “Hukum Persaingan Usaha”, cet. I. (Jakarta: Ghalia Indonesia. 2002). hat. 75 .

22 Indonesia (B). Undang-undang Tentang Larangan Praktek Monopoli dan Persaingan Usaha Tidak Sehat. Op. Cit., Pasal 3. 
2. productive efficiency (yaitu menghasilkan barang atau jasa dengan harga produksi serendah mungkin, yang mempergunakan sumberdaya seminimum mungkin). ${ }^{23}$

Dalam rangka menciptakan iklim yang kondusif bagi persaingan usaha yang sehat, hukum persaingan usaha bergantung sepenuhnya kepada sistem operasional pasar untuk:

1. menentukan jenis barang atau jasa yang akan dihasilkan;

2. menentukan bagaimana sumber-sumber daya yang ada tersebut dapat dialokasikan dengan baik dalam suatu proses produksi; dan

3. menentukan kepada siapa hasil produksi akan didistribusikan. $^{24}$

\section{Posisi Dominan}

Pengaturan lebih lanjut mengenai posisi dominan ditegaskan dalam pasal 25 ayat (2) undang-undang persaingan usaha, dimana dinyatakan bahwa suatu pelaku usaha atau sekelompok pelaku usaha dianggap memiliki "posisi dominan apabila:

1. suatu pelaku usaha atau satu kelompok pelaku usaha menguasai $50 \%$ atau lebih pangsa pasar atau jenis barang atau jasa tertentu; atau

2. dua atau tiga pelaku usaha atau kelompok pelaku usaha menguasai $75 \%$ atau lebih pangsa pasar satu jenis barang atau jasa tertentu. ${ }^{25}$

Terdapat beberapa bentuk Posisi Dominan yang dilarang dalam undang-undang ini. Namun dalam tulisan ini penulis hanya akan memaparkan bentuk yang sangat berkaitan dengan pokok masalah tulisan ini. Bentuk Posisi Dominan tersebut adalah Penggabungan, Peleburan, Pengambilalihan. Pengaturan mengenai ketiganya terdapat dalam pasal 28 dan pasal 29 undangundang persaingan usaha.

23 Gunawan Widjaja, "Merger dalam Perspektif Monopoli", (Jakarta: Rajawali Press. 2001), hal. 7 s.d. 8.

\footnotetext{
${ }^{24}$ Ibid., hal 8 .

25 Ibid, hal.85.
} 
1) Penggabungan (Pasal 28 ayat (1))

Penggabungan (merger) adalah suatu penggabungan badan usaha dengan atau tanpa likuidasi, dimana badan usaha yang satu bubar secara hukum dan yang lainnya tetap ada dengan nama yang sama. ${ }^{26}$ Penggabungan dibagi menjadi:

a) Penggabungan Horizontal antar perusahaan yang semula langsung bersaing dalam pasar yang sama dan terhadap produk yang sama ${ }^{27}$;

b) Penggabungan Vertikal antar Perusahaan yang mempunyai hubungan sebagai pelanggan dan pemasok atau antara perusahaan yang berbeda dalam tingkat proses produksi ${ }^{28}$;

c) Penggabungan Konglomerat, merupakan gabungan antara dua perusahaan atau lebih yang sama sekali tidak punya keterkaitan bidang usaha satu sama lain. ${ }^{29}$

2) Peleburan (Pasal 28 ayat (1))

Menurut pasal 1 angka 1 Peraturan Pemerintah nomor 27 tahun 1998, Peleburan adalah: "perbuatan hukum yang dilakukan oleh dua atau lebih perusahaan untuk meleburkan diri dengan cara membentuk suatu perseroan baru dan masing-masing perseroan yang meleburkan diri menjadi bubar"

Dengan demikian, perbedaan antara peleburan dan penggabungan adalah terletak pada konsekuensi hukumnya. Pada perbuatan hukum peleburan eksistensi dari masing-masing perusahaan yang meleburkan diri menjadi berakhir dan timbul perusahaan baru. Persamaan dari kedua-nya ialah sama-sama dapat dilakukan dengan tanpa dilikuidasi. $^{30}$

${ }^{26}$ Eiyta Ras Ginting, "Hukum Anti Monopoli Indonesia Analisis dan Perbandingan Undang-undang No. 5 Tahun 1999", cet. I. (Bandung: PT. Citra Aditya Bakti. 2001), hal. 84.

${ }^{27} \mathrm{Ibid}$.

${ }^{28}$ Ditha Wiradiputra. "Pengantar Hukum Persaingan Usaha di Indonesia," (Module for Retooling Program under Employee Graduates at Priority Diciplines under TSDP DIKTI. Jakarta, 2004), hal. 14.

29 Ibid.

${ }^{30}$ Elyta Ras Ginting. Op. Cit., hal. 86. 
3) Pengambilalihan (pasal 28 ayat ( 2 ;

Pengambilalihan kepemilikan oleh suatu perusahaan terhadap perusahaan lainnya (akuisisi), dapat dilakukan terhadap perusahaan yang selevel (vertikal). Bentuk dari akuisisi ada dua, yaitu ${ }^{31}$ :

a) Akuisisi Saham

Merupakan salah satu bentuk akuisisi yang paling umum ditemui, yang dapat dilakukan dengan cara:

1. membeli seluruh maupun sebagian saham yang telah dikeluarkan oleh perseroan; maupun dengan atau tanpa

2. melakukan penyetoran atas sebagian maupun seluruh saham yang belum dan akan dikeluarkan perseroan.

b) Akuisisi Asset

Akuisisi asset secara sederhana dapat dikatakan merupakan:

1. jual beli asset antara pihak yang melakukan akuisisi asset sebagai pihak pembeli dengan pihak yang diakuisisi assetnya sebagai pihak penjual;

2. perjanjian tukar menukar antar asset yang diakuisisi dengan suatu kebendaan lain milik dari pihak yang melakukan akuisisi.

Alasan dilarangnya penggabungan, peleburan, dan pengambilalihan oleh hukum persaingan usaha adalah ketiganya dianggap berpotensi menimbulkan dampak negatif terhadap persaingan pasar dalam bentuk:

1. terciptanya atau bertambahnya konsentrasi pasar yang dapat menyebabkan harga produk semakin tinggi;

2. kekuatan pasar menjadi semakin besar yang dapat mengancam pebisnis kecil. ${ }^{32}$

Bergabung untuk menjadi besar, kuat dan efisien pada dasarnya adalah hak semua pengusaha. Akan tetapi tidak pula dapat disangkal bahwa perusahaan yang terlalu besar dan kuat sangat sangat mudah menyalahgunakan kelebihan itu.

\footnotetext{
${ }^{31}$ Ibid. hal. $49-50$

${ }^{32}$ Ibid.
} 


\section{Pengaturan Kanal Frekuensi Radio Dalam Perspektif UU No. 32/ 2002 dan UU No. 5/1999}

\section{A. Pengaturan Kanal Frekuensi Radio}

\section{Arti Penting Pengaturan Kanal Frekuensi Radio}

Berdasarkan uraian pada bagian kerangka konsepsional sebelumnya, dapat diketahui bahwa kanal frekuensi radio merupakan bagian terkecil dari spektrum frekuensi radio yang dipetakan pada jenis-jenis frekuensi tertentu. ${ }^{33}$ Sedangkan spektrum frekuensi radio sendiri merupakan gelombang eloktromagnetik yang dipergunakan untuk penyiaran, dimana melalui gelombang inilah suara, gambar, dan sebagainya dihantarkan. Gelombang ini merambat di udara serta ruang angkasa tanpa terlihat, tanpa dapat dirasakan oleh indra manusia, dan tanpa sarana penghantar buatan. Meskipun spektrum frekuensi ini disebut dengan spektrum frekuensi radio, namun frekuensi tersebut juga digunakan dalam penyiaran televisi. ${ }^{34}$

Sebagai salah satu jenis spektrum ${ }^{35}$, spektrum frekuensi radio ini terbagi atas beberapa jenis frekuensi yang terdiri dari: Very Low Frequency (VLF); Low Frequency (LF); Medium Frequency (MF); High Frequency (HF); Very High Frequency (VHF); Ultra High Frequency (UHF); Super High Frequency (SHF); Extremely High Frequency (EHF). Pada jenis UHF-lah penyiaran oleh media televisi dapat lakukan dengan baik, pasalnya pada panjang jenis frekuensi ini pesan atau rangkaian pesan baik dalam bentuk suara

${ }^{33}$ Satu diantara sekian banyak jenis frekuensi yang didalamnya dipetakan kanal spektrum frekuensi radio adalah jenis frekuensi UHF.

${ }^{34}$ Selain untuk kegiatan penyiaran spektrum frekuensi radio juga digunakan untuk kepentingan bisnis, komunikasi, mendukung keselamatan perjalanan baik di darat, laut dan udara, menyediakan sarana komunikasi yang efektif untuk jasa gawat darurat (emergency) dan bahkan untuk keperluan angkatan bersenjata, serta riset ilmiah. Sumber slide presentasi berudul: Manajemen Spektrum Frekuensi Radio dan Orbit Satelit Nasional. Direktorat Bina Spektrum Frekuensi Radio dan Orbit Satelit-Direktorat Jenderal Pos dan TelekomunikasiDepartemen Perhubungan. hal.4

${ }^{35}$ Jenis spektrum setidaknya ada 3 macam, yaitu sonar, spektrum frekuensi radio, dan spektrum frekuensi sinar. Sumber slide presentasi berudul: Manajemen Spektrum Frekuensi Radio dan Orbit Satelit Nasional. Direktorat Bina Spektrum Frekuensi Radio dan Orbit Satelit-Direktorat Jenderal Pos dan Telekomunikasi-Departemen Perhubungan. Ibid., hal.9. 
gambar, atau suara dan gambar, atau yang berbentuk grafis, karakter, baik yang bersifat interaktif maupun tidak, dapat disiarkan dengan baik. ${ }^{36}$

Masing-masing jenis frekuensi tersebut mempunyai panjang frekuensi yang berbeda-beda. ${ }^{37}$ Panjang frekuensi tersebut menunjukkan bahwa spektrum frekuensi radio merupakan sumber daya alam yang terbatas. Karena keterbatasan panjang frekuensi ini, maka terhadap kanal frekuensi radio di dalamnya, harus dibuatkan suatu pengaturan yang baik, sehingga dapat dicegah terjadinya interferensi yang dapat mengganggu penyiaran, dan atau sarana komunikasi lain. ${ }^{38}$

\section{Pengaturan Kanal Frekuensi Radio}

Dewasa ini pengaturan kanal frekuensi radio dirumuskan dalam KEPMENHUB No.KM.76/2003. Berdasarkan nama peraturan ini dapat diketahui bahwa kanal frekuensi radio yang menjadi objek atur tersebut berada pada jenis frekuensi UHF. ${ }^{39}$ Pada jenis frekuensi ini kegiatan penyiaran dapat dilakukan oleh 2 jenis standar sistem televisi siaran, yaitu: standar sistem televisi siaran analog dan digital. ${ }^{40}$

Berkaitan dengan 2 macam jenis standar televisi siaran tersebut, perlu juga diketahui bahwa seluruh lembaga penyiaran jasa penyiaran televisi saat ini menggunakan standar sistem televisi siaran analog. Dengan menggunakan standar sistem televisi siaran jenis tersebut, maka satu lembaga penyiaran hanya

${ }^{36}$ Berdasarkan hasil diskusi penulis dengan Bapak Denny Setiawan. Kepala Bagian Perizinan Direktorat Spektrum Frekuensi Radio dan Orbit Satelit Ditjen Postel. Depkominfo. Pada 15 Maret 2007.

${ }^{37}$ Ibid. Panjang pita frekuensi yaitu: VLF $(9 \mathrm{kHz}-30 \mathrm{kHz}) ; \mathrm{LF}(30 \mathrm{kHz}-300 \mathrm{kHz})$; $\mathrm{MF}(300 \mathrm{kHz}-3 \mathrm{MHz})$; HF $(3 \mathrm{MHz}-30 \mathrm{MHz})$; VHF $(30 \mathrm{MHz}-300 \mathrm{MHz}) ; \mathrm{UHF}(300 \mathrm{MHz}-3 \mathrm{GHz})$; SHF $(3 \mathrm{GHz}-30 \mathrm{GHz})$; EHF $(30 \mathrm{GHz}-300 \mathrm{GHz})$.

${ }^{38}$ Sumber slide presentasi berjudul: Prinsip perencanaan frekuensi TV Siaran di Indonesia 2005. Ditjen Postel Deparatemen Komunikasi dan Informatika. tulisan ini.

${ }^{39}$ Lihat nama lengkap peraturannya pada bagian metode penulisan pada bab 1

${ }^{40}$ Indonesia (C), KEPMENHUB No. KM.76/2003, Op. Cit,. Pasal 2 ayat (1). 
dapat menempati satu kanal yang disediakan pada setiap wilayah siaran. $^{4 !}$

Pemetaan kanal frekuensi radio tersebut menegaskan bahwa pada setiap wilayah siaran ditentukan hanya terdapat 7, 13 atau sebanyak-banyaknya adalah 14 kanal frekuensi radio. dalam pemetaan ini, juga ditentukan bahwa bagi wilayah siaran dengan alokasi kanal frekuensi radio sebanyak 7 kanal frekuensi, maka 1 kanal frekuensi diantaranya dialokasikan untuk kanal bagi transisi televisi digital, ${ }^{42}$ sedangkan untuk wilayah siaran dengan alokasi kanal frekeunsi radio sebanyak 13 atau 14 kanal frekuensi radio, maka 2 kanal frekuensi diantaranya disediakan untuk kanal transisi televisi digital. ${ }^{43}$ Saat ini penggunaan kanal frekuensi radio bagi Lembaga Penyiaran Swasta masih menggunakan teknologi analog. Dengan penggunaan teknologi ini, berarti bahwa penggunaan 1 (satu) kanal frekuensi radio hanya dapat diberikan untuk 1 (satu) stasiun televisi. Hal tersebut kebalikan dari sistem digital, yang memungkinkan keberadaan beberapa stasiun televisi dalam 1 (satu) kanal frekuensi. ${ }^{44}$

\section{B. Pengaturan Kanal Frekuensi Radio dalam Perspektif UU No. $32 / 2002$}

\section{Kanal Frekuensi Radio Sebagai Ranah Publik}

Dalam undang-undang ini disebutkan bahwa spektrum frekuensi radio adalah ranah publik. Ini berarti kepemilikan gelombang elektromagnetik tersebut merupakan hak seluruh masyarakat Indonesia, sehingga penguasaan atas kanal ini pun

${ }^{41}$ Op. Cit. Berdasarkan hasil diskusi penulis dengan Bapak Denny Setiawan. Kepala Bagian Perizinan Direktorat Spektrum Frekuensi Radio dan Orbit Satelit Ditjen Postel. Depkominfo. Pada 15 Maret 2007. Hasil wawancara ini juga sesuai dengan hasil wawancara Elpi Nazmuzzaman, yang kemudian dituangkannya pada artikelnya yang berjudul "Persaingan TV Swasta: Nasional atau Lokal?", Kompetisi (Edisi VII).

${ }^{42}$ Indonesia. Op. Cit., Pasal 6 ayat (2).

${ }^{43}$ Ibid., Pasal 6 ayat (1).

${ }^{44}$ Berdasarkan hasil diskusi penulis dengan Bapak Denny Setiawan. Kepala Bagian Perizinan Direktorat Spektrum Frekuensi Radio dan Orbit Satelit Ditjen Postel. Depkominfo. Pada 15 Maret 2007. 
harus digunakan untuk sebesar-besarnya kemakmuran rakyat. ${ }^{45}$ Penggunaan kata "rakyat" di sini, tentunya bukan hanya menunjuk pada segelintir orang dan/atau pada satu golongan tertentu saja, melainkan kepada seluruh rakyat Indonesia.

Sejalan dengan pembahasan pada bagian tinjauan UU No.32/2002 di atas, maka dalam penyelenggaraan penyiaran yang berorientasi kemakmuran rakyat harus dilakukan dengan melibatkan partisipasi masyarakat itu sendiri. Dimana dalam hal wujud partisipasi tersebut dapat dilihat melalui keragaman kepemilikan dan keragaman isi siaran.

\section{Keberagaman Kepemilikan dan Keragaman Isi}

\subsection{Keberagaman Kepemilikan}

Penegakkan prinsip keberagaman kepemilikan ini dalam prakteknya masih mengalami distorsi Distorsi tersebut muncul sebagai akibat tidak diaturnya secara tegas pemetaan penggunaan kanal frekuensi radio untuk lembaga penyiaran televisi dalam KEPMENHUB KM.76/2003. Dalam peraturan tersebut pemetaan kanal frekuensi radio yang secara jelas disebutkan adalah pemetaan untuk transisi televisi digital. Inipun dalam prakteknya masih terjadi pelanggaran, karena ternyata hanya 1 (satu) kanal saja yang diperuntukkan untuk transisi televisi digital, dari yang diamanatkan KEPMENHUB KM.76/2003 yaitu 2 (dua) kanal. Pertannyaannya kemudian adalah bagaimana dengan 12 kanal yang tidak dialokasikan peruntukkannya secara jelas? Tentunya tidak akan ada sanksi bila satu pihak memiliki ke-12 kanal itu sekaligus, pasalnya tidak ada satu ketentuan akan memberikan hukuman pada pihak terkait.

Penggunaan kanal frekuensi radio oleh "segelintir orang" saja, justru akan menjadi semakin nyata. Terlebih dengan adanya aturan menganai pemusatan kepemilikan sebagaimana dijelaskan pada pasal 32 ayat 1 PP No.50/2005, yang selengkapnya berbunyi:

Pemusatan kepemilikan dan penguasaan lembaga penyiaran swasta jasa penyiaran televisi oleh 1 (satu) orang atau 1 (satu) badan hukum, baik di satu wilayah siaran maupun di beberapa wilayah siaran di seluruh wilayah Indonesia dibatasi sebagai berikut:

${ }^{45}$ Indonesia (B), Op. Cit.. Pasal 6 ayat (2). 
a. 1 (satu) badan hukum hanya boleh memiliki 2 (dua) izin penyelenggaraan penyiaran jasa penyiaran televisi, yang berlokasi di 2 (dua) provinsi yang berbeda;

b. paling banyak memiliki saham 100\% (seratus perseratus) pada badan hukum ke-1 (kesatu);

c. paling banyak memiliki saham $49 \%$. (empat puluh sembilan perseratus) pada badan hukum ke-2 (kedua);

d. paling banyak memiliki saham $20 \%$ (dua puluh perseratus) pada badan hukum ke-3 (ketiga);

e. paling banyak memiliki saham 5\% (lima perseratus) pada badan hukum ke-4 (keempat, dan seterusnya;

f. badan hukum sebagaimana dimaksud pada huruf b, huruf c, huruf $\mathrm{d}$, dan huruf e, berlokasi di beberapa wilayah provinsi yang tersebar di seluruh wilayah Indonesia.

Pengaturan akan hal ini, sangat mempengaruhi pemetaan alokasi kanal frekuensi radio yang ada. Dengan ketentuan tersebut berarti dimungkinkan bahwa seseorang ataupun badan hukum yang memiliki lebih dari satu lembaga penyiaran jasa penyiaran televisi untuk dapat menguasai lebih dari 1 kanal pada satu wilayah siaran. Ini tercermin dari kata-kata yang penulis garis bawahi di atas. Berdasarkan hal ini maka pemetaan kanal frekuensi radio dapat diokupasi oleh seseorang dan/atau badan hukum tertentu yang memiliki lembaga penyiaran, dengan mana okupasi itu dilakukan pada beberapa kanal frekuensi pada satu wilayah siaran.

Seyogyanya untuk dapat mewujudkan keragaman kepemilikan maka keberadaan kanal-kanal frekuensi pada satu wilayah siaran dimiliki oleh pemilik yang berbeda-beda, misalnya pada wilayah siaran JABODETABEK yang memiliki 14 kanal frekuensi. Okupasi atas 14 kanal itu baru dikatakan mendukung realisasi prinsip keragaman kepemilikan bila 14 kanal tersebut dimiliki oleh pemilik yang berbeda-beda. Kenyataannya tidaklah demikian,buktinya diantara kanal-kanal tersebut ada yang dikuasai oleh beberapa badan hukum tertentu yang memiliki lembaga penyiaran tertentu dengan izin penggunaan kanal lebih dari satu kanal, contohnya adalah penguasaan kanal oleh PT.MNC melalui media televisinya yaitu RCTI (kanal 43),Global TV (kanal 51), dan TPI (kanal 37). Selain PT.MNC, kelompok lain yang juga mengendalikan penggunaan kanal frekuensi radio secara bersamasama adalah Trans-Corp, dengan kepemilikan atas 2 (dua) TV 
Swasta Nasional, yaitu TRANS TV, dan TV 7. Selanjutnya juga kelompok yang dibangun oleh Lativi dan ANTV. ${ }^{46}$

Penggunaan kanal frekuensi radio oleh kelompok-kelompok tersebut di atas adalah suatu bentuk ketidakefisienan dalam memanfaatkan sumber daya alam yang terbatas. Dikatakan demikian, karena pemberian izin untuk menggunakan kanal frekuensi radio pada satu kelompok televisi, sama saja dengan memberikan izin untuk menggunakan beberapa kanal frekuensi radio kepada "satu tangan". Fenomena ini tentunya sangat bertentangan dengan prinsip keberagaman kepemilikan untuk mewujudkan partisipasi publik.

\subsection{Keberagaman Isi}

Tuntutan untuk mewujudkan realisasi prinsip ini pada awalnya muncul akibat adanya keragaman permasalahan sosial yang dihadapi oleh masyarakat di masing-masing daerah yang berbeda, yang pada akhirnya melahirkan tuntutan atas solusi masalah atau pemenuhan kebutuhan yang berbeda-beda pula, misalnya terhadap masalah kerusuhan di Sampit, Kalimantan Timur dan permasalahan gempa bumi di Yogyakarta. Terkait atas 2 (dua) jenis masalah sosial pada 2 (dua) daerah yang berbeda itu, tentunya membutuhkan suatu solusi yang tidak sama, misalnya untuk masalah kerusuhan, maka yang dibutuhkan adalah terciptanya suatu perdamaian antra kedua belah pihak terkait. Dimana perdamaian tersebut baru akan tercipta melalui suatu perundingan bersama antara pihak yang bertikai dengan pemerintah sebagai fasilitator guna terwujudnya hal itu. Sedangkan untuk masalah gempa bumi, maka dibutuhkan bantuan dari pemerintah yang berupa bantuan sandang, pangan, dan/atau perbaikan atas infrastruktur-infrastruktur yang rusak. ${ }^{47}$

Untuk mempercepat proses perdamaian atau untuk distribusi bantuan atas permasalahan sosial di atas, maka salah satu jalan yang dapat ditempuh adalah dengan mewujudkan konsepnya penyelenggaraan penyiaran melalui televisi berjaringan dan/atau

${ }^{46}$ Direktorat Kebijakan Persaingan Sekretariat Komisi Pengawas Persaingan Usaha (KPPU), Laporan Evaluasi Kebijakan Pemerintah Yang Terkait Dengan Persaingan Usaha Dalam Industri Penyiaran Televisi 2007, hal. 43.

${ }^{47}$ Berdasarkan hasil diskusi penulis dengan bapak Elpi Nazmuzzaman, Anggota Direktorat Kebijakkan Komisi Pengawas Persaingan Usaha, pada 12 April 2007, pukul 10.30 BBWI. 
televisi lokal di setiap daerah. Pada kenyataannya sampai saat ini baru hanya METRO-TV yang membuka stasiun berjaringan di daerah, sepanjang yang penulis ketahui hanya baru didirikan di PAPUA.

Dari dua jalan yang dapat ditempuh tersebut, hanya jalan dengan mendirikan televisi lokal-lah yang lebih banyak dilakukan saat ini. Dari data yang penulis dapatkan Indonesia saat ini telah memiliki setidaknya 129 stasiun televisi lokal yang tersebar di hampir seluruh kota besar di Indonesia. ${ }^{48}$ Jumlah ini sesungguhnya terhitung masih sedikit dibandingkan jumlah kebutuhan televisi lokal di seluruh daerah di Indonesia.

Jika keberadaan televisi lokal dikaitkan dengan pengaturan pemetaan kanal frekuensi radio saat ini maka akan terlihat bahwa pengaturan pemetaan tersebut tidak memfasilitasi bagi pertumbuhan televisi lokal di setiap daerah. Pasalnya dengan tidak dialokasikan secara tegas pada pengaturan pemetaan tersebut, praktis kanal yang tersedia untuk televisi lokal di daerah hanya satu. Hal ini menimbulkan masalah tersendiri pada pertumbuhan televisi lokal itu, karena di satu daerah mungkin saja muncul lebih dari satu televisi, seperti contohnya di daerah atau wilayah siaran DKI Jakarta, telah muncul televisi lokal yang terdiri atas Ochannel, JAK-TV, dan Spacetoon. Dari 3 (tiga) stasiun televisi lokal tersebut hanya Spacetoon-lah yang benar telah mengokupasi atau menguasai 1 (satu) kanal pada wilayah siaran DKI Jakarta, sementara 2 (dua) televisi lainnya telah mengokupasi kanal frekuensi pada wilayah siaran lain, O-channel pada kanal frekuensi 33, wilayah siaran Pelabuhan Ratu, ${ }^{49}$ dan Jak-TV pada kanal frekuensi 55, wilayah siaran Purwakarta. ${ }^{50}$ kedua televisi ini dapat disiarkan dengan menghadapkan pemancar-pemancarnya ke wilayah siaran DKI Jakarta, dan karena kebetulan tidak terjadi inteferensi atas pemancaran tersebut, maka siaran kedua televisi ini dapat ditangkap secara jernih diwilayah siaran DKI Jakarta. ${ }^{51}$

48 Data dapat dilihat pada bagian Lampiran tulisan ini. Direktorat Kebijakan Persaingan Sekretariat Komisi Pengawas Persaingan Usaha (KPPU)., op.cit., hal. 41.

${ }^{49}$ Lampiran IV KEPMENHUB KM.76 2003 jo. <www.ochanneltv.com>, diakses pada 19 April 2007.

50 Lampiran IV KEPMENHUB KM.76 2003 jo. <http://id.wikipedia.org/ wiki/JakTV>, diakses pada 19 April 2007. 
Terhadap fenomena di atas, apa yang dilakukan O-Channel dan Jak TV, merupakan suatu penyelenggaraan penyiaran televisi lokal yang tidak ideal. ${ }^{52}$ Seharusnya karena menggunakan kanal frekuensi di wilayah siaran terkait, maka penyiaran yang diadakan oleh kedua stasiun televisi tersebut harus berorientasi kepada wilayah siaran dimana kanal frekuensi mereka dipetakan. Namun tidak demikian kenyataannya, dalam hal ini dapat penulis kemukakan contoh acara yang justru tidak berorientasi kepada wilayah siaran dimana kanal frekuensi yang mereka, masingmasing televisi itu, gunakan. Acara-acara tersebut contohnya Profesi Jakarta di O channel dan Suara Jakarta di Jak TV. Kedua acara tersebut lebih banyak menampilkan kehidupan dan pola hidup masyarakat di Jakarta. Fenomena ini jelas justru tidak mendukung realisasi dari prinsip keberagaman isi di atas, yang menghendaki penyiaran televisi lokal untuk dapat lebih mengekspose budaya, pola hidup, kemajuan daerah terkait, dan hal-hal lainnya yang berkaitan dengan wilayah siaran tersebut. "Fenomena O-channel dan Jak TV" ini tidak sepatutnya terjadi bila pengaturan penggunaan kanal frekuensi radio lebih dapat memfasilitasi pertumbuhan televisi lokal di setiap daerah, yang mungkin hadir lebih dari satu stasiun televisi di setiap daerah.

\section{Pengaturan Kanal Frekuensi Radio Dalam Perspektif UU No. $5 / 1999$}

\section{Pengaturan Kanal Frekuensi Penyiaran dan Hukum Persaingan Usaha}

Sebagai bagian terkecil dari spektrum frekuensi radio, kanal frekuensi radio sangat penting keberadaannya bagi dunia industri, dalam hal ini adalah industri pertelevisian. Penggunaan kanal frekuensi radio ini sangat berkaitan erat dengan persaingan usaha di bidang pertelevisian. Dengan penguasaan lebih banyak atas kanal-kanal tersebut memungkinkan pelaku usaha di bidang pertelevisian yang mempunyai izin dalam menggunakan kanal terkait, dapat meraih keuntungan yang lebih dari pelaku usaha

${ }^{51}$ Berdasarkan hasil diskusi penulis dengan Bapak Jimmy Silalahi, Ketua Asosiasi Televisi Lokal Indonesia (ATVLI), pada 12 April 07, pukul 15.30 BBWI.

${ }^{52} \mathrm{Op}$. Cit. Dalam hal diversity of content, dengan tumbuhnya televisi-televisi lokal di daerah, harapannya adalah televisi menjadi lebih dekat dengan kebutuhan pemirsanya. " $P P$ Penyiaran dan Demokratisasi", 
yang hanya menguasai sedikit atas kanal frekuensi radio itu. Begitu strategisnya keberadaan kanal frekuensi ini, maka dalam pengaturannya harus bersesuaian dengan tujuan Hukum Persaingan Usaha itu sendiri, sebagaimana telah disebutkan pada BAB II, bagian tinjauan atas UU No.5/1999.

\section{Persaingan pada Industri Pertelevisian di Indonesia}

Perkembangan industri pertelevisian Indonesia saat ini sudah sedemikian pesatnya. Pasalnya industri ini teleh diramaikan oleh begitu banyak media televisi yang sangat bervariasi. Beberapa lembaga penyiaran yang sah keberadaannya berdasarkan UU No.32/2002 diantaranya adalah Lembaga Penyiaran Publik, Lembaga Penyiaran Swasta, Lembaga Penyiaran Berlangganan, dan Lembaga Penyiaran Komunitas. ${ }^{53}$

Berdasarkan hubungan antara pemirsa dengan stasiun televisi, maka lembaga-lembaga penyiaran tersebut dapat dikelompokkan menjadi 4 (empat) macam media televisi. Pertama adalah TV Free to air pada jenis televisi ini pemirsa tidak dibebankan langsung atas siaran yang mereka nikmati, adapun lembaga penyiaran yang dapat masuk pada kategori ini adalah Lembaga Penyiaran Swasta. Televisi jenis ini mendapatkan biaya operasionalnya dari pemasangan iklan oleh pengiklan. Kedua adalah Televisi Berbayar atau Televisi Berlangganan, dimana pemirsa dibebankan biaya tertentu atas siaran yang mereka pilih, baik melalui kabel maupun melalui satelit. Ketiga dan keempat berturut-turut adalah Televisi Publik dan Televisi Komunitas yang siarannya lebih menekankan pada kepentingan pemirsa bukan pada pemasang iklan maupun hubungan komersial. 2 (dua) jenis televisi ini masing-masing mendapatkan pemasukan utama dari kas negara untuk Televisi Publik dan dari lembaga yang mendirikan Televisi Komunitas terkait untuk Televisi Komunitas. Persaingan yang akan dibahas pada tulisan ini adalah persaingan pada jenis TV Free to air. Hal ini dikarenakan pada kenyataannya sebagian besar kanal frekuensi radio saat ini tengah dikuasai oleh TV Free to air.

TV Free to air tersebut di atas dapat dibagi menjadi 2 (dua) jenis televisi yaitu TV swasta nasional dan TV swasta Lokal.

${ }^{53}$ Indonesia (B), Op. Cit., Pasal 13 ayat (2). 
Berkaitan dengan pengunaan kanal frekuensi radio, kenyataannya dari 14 (empat belas) kanal frekuensi radio yang dipetakan, 10 (sepuluh) diantaranya telah digunakan oleh televisi swasta nasional. Sedangkan sisa 3 (tiga) kanal yang tersedia dicadangkan 1 (satu) kanal untuk kepentingan pertahanan dan keamanan dan 1 (satu) kanal untuk percobaan siaran digital. Dalam hal ini praktis kanal yang tersisa untuk televisi lokal disetiap daerah hanya 1 (satu) kanal.

Penggunaan kanal frekuensi radio oleh ke-10 televisi swasta nasional itu dilakukan secara berkelompok. Dimana kelompokkelompok tersebut terbentuk melalui mekanisme seperti akuisisi. Dari sudut pandang Hukum Persaingan Usaha, trend pengelompokan pada beberapa lembaga penyiaran di atas mengakibatkan kanal frekuensi radio dikuasai oleh sedikit pelaku usaha. Hal tersebut menjadikan pelaku-pelaku usaha terkait dominan dalam pasar yang bersangkutan. Pasalnya dengan okupasi yang lebih atas kanal frekuensi radio pada satu wilayah siaran maka akan memungkinkan kelompok-kelompok usaha terkait dapat lebih menguasai belanja iklan yang ada pada wilayah siaran itu. Terlebih juga dengan adanya aturan yang membolehkan stasiun televisi swasta nasional untuk mempunyai kepemilikan dan isi siaran hingga $90 \%$. Dengan aturan ini tentunya ini tentunya juga akan menjadikan televisi swasta nasional lebih diminati oleh pemasang iklan dibandingkan televisi swasta lokal. ${ }^{54}$

Berdasarkan kenyataan pada uraian diatas, jika kemudian dihubungkan dengan tinjauan atas UU No.5/1999 mengenai bentuk posisi dominan sebelumnya, maka dapat terlihat bahwa akuisisi dan/atau merger yang telah melahirkan kelompokkelompok stasiun televisi itu, merupakan akuisisi dan/atau merger yang berpotensi memiliki potensi persaingan usaha yang tidak sehat. Pelaku usaha yang menggunakan beberapa kanal frekeunsi radio sekaligus pada suatu industri yang sama atau pada suatu pasar yang bersangkutan, akan memiliki kekuatan monopoli yang cukup besar. Dalam hal ini, meskipun masih harus di teliti lebih jauh apakah terdapat penyalahgunaan posisi dominan oleh masing-masing kelompok stasiun televisi tersebut ${ }^{55}$, namun

${ }^{54}$ Indonesia (D), Peraturan Pemerintah Tentang Penyelenggaraan Penyiaran, PP No.50/2005, LN No. 127 Tahun 2005, TLN No.4566, Pasal 17 ayat (2). 
dengan diketahui bahwa keberadaan mereka, kelompok-kelompok stasiun televisi itu, dapat berpotensi untuk menimbulkan persaingan usaha yang tidak sehat dalam suatu pasar yang bersangkutan, maka hal ini setidaknya dapat menjadi acuan bagi pengaturan penggunaan atau pemetaan atau alokasi yang lebih baik atas kanal frekuensi radio saat ini.

\section{Penutup}

\section{A. Kesimpulan}

Berdasarkan uraian pada maka dapat ditarik beberapa kesimpulan, guna menjawab pokok permasalahan pada tulisan ini. Kesimpulan tersebut antara lain:

1. Pengaturan atas penggunaan atau pemetaan atau alokasi kanal frekuensi radio dalam perspektif UU No.32/2002, adalah pengaturan yang dapat mewujudkan partisipasi publik. Dimana partisipasi publik tersebut dilakukan berdasarkan dua cara yaitu diersity of ownership dan diversity of content.

2. Pengaturan atas penggunaan atau pemetaan atau alokasi kanal frekuensi radio dalam perspektif UU No.5/1999 adalah pemetaan yang dapat menjamin terbentuknya persaingan usaha yang sesuai dengan tujuan Hukum Persaingan Usaha terkait.

3. Berdasarkan pada uraian pada BAB III di atas, dapat diketahui bahwa Pengaturan penggunaan kanal frekuensi radio saat ini, belum sejalan dengan semangat baik UU No.32/2002 maupun UU No.5/1999.

\section{B. Saran}

Adapun saran penulis terhadap permasalah pengaturan penggunaan kanal frekuensi radio pada tulisan ini adalah:

${ }^{55}$ Posisi Dominan pada UU No. 5/1999 dirumuskan secara Rule of Reason. Pendekatan rule of reason adalah suatu pendekatan yang menentukan bahwa meskipun suatu perbuatan telah memenuhi rumusan undang-undang, namun jika ada alasan objektif (biasanya ekonomi) yang dapat membenarkan perbuatan tersebut, maka perbuatan itu bukan merupakan suatu pelanggaran. Artinya penerapan hukumnya bergantung pada akibat yang ditimbulkannya, apakah perbuatan itu telah menimbulkan praktek monopoli atau persaingan usaha yang tidak sehat, karena titik beratnya adalah unsur materiil dari perbuatannya. Susanti Adi Nugroho, Pengaturan Hukum Persaingan Usaha di Indonesia (Jakarta: Puslitbang-Diklat Mahkamah Agung, 2001), hal. 28 - 29. 
1. harus segera dibentuk suatu pengaturan baru pada pemetaan kanal frekuensi radio;

2. pengaturan baru tersebut harus menjamin di alokasikannya beberapa slot kanal untuk keperluan televisi lokal;

3. pengaturan mengenai ketentuan pemusatan kepemilikan media televisi pada pasal 32 ayat 1 serta ketentuan relai dan siaran bersama pada pasal 17 ayat 2 PP No.50/2005 harus segera diperbaharui, dengan catatan bahwa perbaharuan atas aturan tersebut menguatkan posisi televisi lokal, dengan tidak mengizinkan pemusatan kepemilikan pada satu wilayah siaran sama, juga dengan memberikan kepemilikan siaran hingga $50 \%$ untuk televisi lokal;

4. mengingat terhadap ketentuan mengenai merger, akuisisi, dan konsolidasi yang diatur pada pasal 28 dan 29 UU No.5/1999, belum ada peraturan pelaksaannya, maka dengan ini pemerintah harus segera dapat membuat peraturan pelaksanaan tersebut, sehingga akan ada suatu payung hukum yang jelas dalam melaksanakan ketentuan-ketentuan terkait;

5. harus diadakan percepatan atas migrasi standar sistem televisi analog kepada digital. 


\section{Daftar Pustaka}

\section{A. Peraturan Perundang-Undangan}

Indonesia, Undang-undang Tentang Pemerintahan Daerah, UU No.32 Tahun 2004, LN No.125 Tahun 2004, TLN No.4437.

, Undang-undang Tentang Penyiaran, UU No.32 Tahun 2002, LN No.72 Tahun 1997, TLN No.4252.

, Undang-undang Tentang Larangan Praktek Monopoli dan Persaingan Usaha Tidak Sehat, UU No.5/1999, LN No.33 Tahun 1999, TLN No. 3817.

, Peraturan Pemerintah Tentang Penyelenggaraan Penyiaran, PP No.50/2005, LN No. 127 Tahun 2005, TLN No.4566.

, Keputusan Menteri Perhubungan Tentang Rencana Induk (Master Plan) Frekuensi Radio Penyelenggaraan Telekomunikasi Khusus Untuk Keperluan Televisi Siaran Analog Pada Pita Ultra High Frequency (UHF), KEPMENHUB No.KM.76/2003.

\section{B. Buku}

Adi Nugroho, Susanti, Pengaturan Hukum Persaingan Usaha di Indonesia (Jakarta: Puslitbang-Diklat Mahkamah Agung, 2001).

Gunawan, Ilham dan Sahrani, M.Martinus, Kamus Hukum, (Jakarta: Restu Agung, 2002).

Mertokusumo, Sudikno, Mengenal Hukum; Suatu Pengantar, Cetakan ke-4, (Yogyakarta: Liberty, 1995).

Ras Ginting, Elyta, Hukum Anti Monopoli Indonesia Analisis dan Perbandingan Undang-undang No.5 Tahun 1999, cet.1, (Bandung: PT. Citra Aditya Bakti, 2001).

Sitompul, Asril, Praktek Monopoli dan Persaingan Usaha Tidak Sehat: Tinjauan Terhadap Undang-undang Nomor 5 Tahun 1999, cet.1, 9 Bandung: Citra Aditya Bakti, 1999).

Siswanto, Arie, Hukum Persaingan Usaha,cet.1, (Jakarta: Ghalia Indonesia, 2002).

Soekanto, Soerjono dan Mamudji, Sri, Penelitian Hukum Normatif, cet. 1., (Jakarta: Rajawali Pers, 1985). 
Tim Penyusun Kamus Pusat Pembinaan dan Pengembangan Bahasa Departemen Pendidikan dan Kebudayaan,Kamus Besar Bahasa Indonesia, cet.3, (Jakarta:Balai Pustaka, 1990).

Widjaja, Gunawan, Merger dalam Perspektif Monopoli, (Jakarta: Rajawali Press, 2001).

Wiradiputra, Ditha, Pengantar Hukum Persaingan Usaha di Indonesia, (Module for Retooling Program under Employee Graduates at Priority Diciplines under TSDP DIKTI, Jakarta, 2004).

\section{Artikel}

Nazmuzzaman, Elpi. Persaingan TV Swasta: Nasional atau Lokal?, Kompetisi, (Edisi VII) : 10.

\section{Internet}

<http://id.wikipedia.org/wiki/JakTV>, diakses tanggal 19 April 2007.

Indonesia Media Law \& Policy Centre (IMLPC) "Menunggu RUU Penyiaran Paling Demokratis". <www.imlpc.or.id/ind/publication/ ar_newsletter/1jan-mar2001/index>, diakses tanggal 13 April 07.

"Ketentuan UU No. 32 tahun 2002 tentang Penyiaran terkait Haluan Dasar, Karakteristik Penyiaran, dan Prinsip Dasar Penyiaran di Indonesia", <www.kpi.go.id>. 07 September 2006.

"PP Penyiaran dan Demokratisasi", <www.pikiran-rakyat.com>, diakses tanggal 13 April 2007.

"Semarak Televisi Lokal", <http://agustianwar.multiply.com/tag/publik>, diakses tanggal 13 April 2007.

<www.ochanneltv.com>, diakses tanggal 19 April 2007.

\section{E. Lain-Lain}

Direktorat Kebijakan Persaingan Sekretariat Komisi Pengawas Persaingan Usaha (KPPU), Laporan Evaluasi Kebijakan Pemerintah Yang Terkait Dengan Persaingan Usaha Dalam Industri Penyiaran Televisi 2007. 
Hasil diskusi penulis dengan Bapak Denny Setiawan. Kepala Bagian Perizinan Direktorat Spektrum Frekuensi Radio dan Orbit Satelit Ditjen Postel, Depkominfo, 15 Maret 2007.

Hasil diskusi penulis dengan Bapak Elpi Nazmuzzaman, Anggota Direktorat Kebijakkan Komisi Pengawas Persaingan Usaha, pada 12 April 2007.

Hasil diskusi penulis dengan Bapak Jimmy Silalahi, Ketua Asosiasi Televisi Lokal Indonesia (ATVLI), pada 12 April 2007.

Slide presentasi berudul: Manajemen Spektrum Frekuensi Radio dan Orbit Satelit Nasional, Direktorat Bina Spektrum Frekuensi Radio dan Orbit Satelit - Direktorat Jenderal Pos dan Telekomunikasi - Departemen Perhubungan.

Slide presentasi berjudul: Prinsip perencanaan frekuensi TV Siaran di Indonesia 2005, Ditjen Postel Deparatemen Komunikasi dan Informatika. 